\title{
Strategi Komunikasi dalam Penerapan Teknologi Usaha Perikanan di Pesisir Selatan Kabupaten Pangandaran
}

\author{
[Communication Strategy for Implementing Information Technology on \\ Fisheries Business in The South Coastal of Pangandaran District]
}

\section{Ani Leilani, Nia Nurfitriana, Adang Kasmawijaya}

Program Studi Penyuluhan Perikanan, Politeknik Ahli Usaha Perikanan Jalan Cikaret Nomor 2 Bogor, Jawa Barat

\begin{abstract}
Abstrak
Dalam mendukung perkembangan usaha perikanan masyarakat, kegiatan pendampingan oleh pemerintah daerah baik berupa informasi teknologi dan peningkatan keterampilan pelaku usaha merupakan salah satu solusi dalam membantu meningkatkan usaha perikanan yang dilakukan oleh masyarakat di pesisir selatan Pangandaran. Tujuan dari pelaksanaan penelitian ini untuk mengidentifikasi karakteristik internal dan eksternal pelaku usaha perikanan, mengetahui bagaimana strategi komunikasi yang digunakan dalam penerapan teknologi pelaku usaha perikanan dan mengetahui efektivitas penerapan teknologi yang diberikan kepada masyarakat pesisir Pangandaran. Metode yang digunakan meliputi metode survei dan diskusi terbatas (Focus Group Discussion) serta pengumpulan data sekunder dari berbagai sumber. Hasil penelitian menunjukkan karakteristik internal dan eksternal pelaku usaha perikanan di pesisir selatan Pangandaran memiliki pengaruh secara simultan dengan penerapan teknologi karena f hitung sebesar $2,50>\mathrm{f}$ tabel sebesar 2,537 dan nilai signifikasi sebesar 0,098<0,1 dengan tingkat kepercayaan sebesar $90 \%$. Penerapan teknologi berpengaruh terhadap strategi komunikasi yang diterapkan pelaku usaha perikanan karena t hitung sebesar 2,307 > t tabel sebesar 2,048 dan nilai signifikasi sebesar 0,000 0,05 dengan tingkat kepercayaan sebesar 95 \%. Strategi komunikasi berpengaruh terhadap motivasi pelaku usaha perikanan karena t hitung sebesar 5,574 > t tabel sebesar 2,048 dan nilai signifikasi sebesar 0,03 0,05 dengan tingkat kepercayaan sebesar $95 \%$.
\end{abstract}

Kata kunci: komunikasi; perikanan; pesisir; strategi; teknologi; usaha

\section{Abstract}

In supporting the development of community fisheries business, mentoring activities by the local government in the form of information technology and improving the skills of businessmen is one of the solutions to help improve the fisheries business carried out by the people on the south coast of Pangandaran. The purpose of this research is to identify internal and external business actors, find out how the communication strategy is used business actors, and the effectiveness of its technology application which is given to Pangandaran's coastal society. The method used is survey method and limited discussion (Focus Group Discussion) along secondary data collection from various sources. The results of the research show that the internal and external characteristics of fisheries business actors on the south coast of Pangandaran have a simultaneous effect on the application of technology because $f$ count is $2.50>\mathrm{f}$ table of 2.537 and a significance value of $0.098<0.1$ with a confidence level of $90 \%$. The application of technology influences the communication strategy applied by fisheries businessmen because $t$ is $2.307>t$ table of 2.048 and the significance value is $0.000<0.05$ with a confidence level of $95 \%$. Communication strategies affect the motivation of fisheries business actors because $t$ is $5.574>t$ table of 2.048 and the significance value is $0.03<0.05$ with a confidence level of $95 \%$.

Keywords: communication; fisheries; coastal; strategy; technology; business 
Penulis Korespondensi

Nia Nurfitriana | e-mail: nia.adie@gmail.com

\section{PENDAHULUAN}

Program kelautan dan perikanan yang telah dilaksanakan sekarang ini, telah berhasil mengubah wajah bidang kelautan dan perikanan Indonesia. Di samping perubahan pada bidang prasarana fisik, teknologi dan produktivitas perikanan, para pelaku usaha perikanan Indonesia juga telah berubah secara lebih nyata. Slamet dalam Padmaningrum (2008) mengungkapkan, secara makro populasi petani telah menjadi lebih sedikit jumlahnya secara persentase tetapi lebih tinggi dalam hal kualitas yang ditandai dengan lebih baiknya tingkat pendidikannya, lebih mengenal era modern, kebutuhan beserta harapanharapannya yang meningkat, dan pengetahuan serta keterampilan usahanya yang juga jauh lebih baik lagi. Pernyataan tersebut dapat diartikan bahwa peran penyuluhan perikanan sangat berperan penting. Hal tersebut berkaitan erat dengan definisi penyuluhan itu sendiri yang merupakan proses perubahan perilaku yang terdiri dari pengetahuan, sikap dan keterampilan di kalangan masyarakat baik itu nelayan, pembudidaya ikan, pengolah ikan maupun petambak garam supaya mereka tahu, mau dan mampu melak- sanakan berbagai perubahan dalam usaha perikanannya. Adapun tujuan perubahan perilaku tersebut demi tercapainya peningkatan produksi, pendapatan yang akan berdampak pada keuntungan serta perbaikan kesejahteraan masyarakat khususnya keluarga melalui pembangunan perikanan (Mardikanto dalam Purnomo, Leilani, dan Nurfitriana 2018).

Memperhatikan keadaan dan perubahan pembangunan kelautan dan perikanan dewasa ini serta tantangan yang ada, perlu dipersiapkan strategi komunikasi pembangunan yang efektif dalam menunjang program pembangunan kelautan dan perikanan. Menurut Mulyana (2012) bahwa strategi pada hakikatnya adalah suatu perencanaan dan manajemen untuk mencapai tujuan tertentu. Baran dan Davis (2010) menyatakan bahwa strategi komunikasi umumnya dirumuskan dengan memperhatikan tiga hal, yaitu khalayak sasaran (receiver), pesan (message) yang akan disampaikan, dan saluran (channel) yang digunakan untuk mencapai tujuan tersebut. Arifin (1984) menyatakan bahwa strategi adalah keseluruhan keputusan kondisional tentang tindakan yang akan dilaksanakan 
dalam mencapai suatu tujuan. Merumuskan strategi komunikasi, berarti merencanakan kondisi dan situasi yang akan mungkin dihadapi di masa depan guna mencapai efektivitas.

Effendy (2013) menyatakan bahwa strategi komunikasi merupakan paduan dari perencanaan komunikasi (communication planning) dan manajemen (communication management) untuk mencapai tujuan. Sedangkan komunikasi adalah proses penyampaian pesan yang dilakukan komunikator kepada komunikan atau penerima. Jika dianalisis pesan komunikasi terdiri dari dua aspek yaitu isi pesan (the content of the message), dan lambang (symbol). Konkretnya isi pesan itu adalah pikiran atau perasaan, lambang adalah bahasa (Effendy 2013). Selain itu, menurut McQuail dan Windahl (2015) unsurunsur komunikasi yang selalu ada dan berproses dalam setiap konteks komunikasi baik itu model komunikasi linier (searah) maupun sirkuler (dua arah) yang terdiri dari: komunikator (source), pesan (message), media (channel), komunikan (receiver), dan efek (effect) dapat memberikan petunjuk hal-hal yang perlu mendapat penekanan untuk merancang strategi komunikasi guna memperoleh komunikasi yang efektif dan maksimal.
Penerapan strategi komunikasi pada salah satu sentra usaha kelautan dan perikanan dilakukan di Kabupaten Pangandaran yang merupakan kabupaten yang sedang berkembang secara pesat saat ini terutama pada sektor kelautan dan perikanan. Usaha-usaha kelautan dan perikanan tumbuh pesat, jumlah kelompok perikanan yang terus bertambah, serta dukungan pemerintah dalam pembangunan pada bidang kelautan dan perikanan. Kabupaten Pangandaran memiliki panjang pantai $91 \mathrm{~km}$ dengan potensi perikanan budidaya dan perikanan tangkap. Perikanan budidaya kabupaten tersebut memiliki luas areal tambak 68,5 Ha dengan jumlah produksi 100 ton dan luas kolam $440,57 \mathrm{Ha}$ dengan jumlah produksi 27 ton pada tahun 2017, sedangkan pada sektor perikanan tangkap khususnya perikanan laut sebesar 2846,07 ton pada tahun 2017 (BPS 2019). Data statistik menggambarkan bahwa Kabupaten Pangandaran merupakan salah satu Kabupaten di Provinsi Jawa Barat yang memberikan kontribusi besar bagi perekonomian negara terutama dari sektor kelautan dan perikanan.

Badan Pengembangan Sumber

Daya Manusia Kelautan dan Perikanan (2016) menyebutkan jumlah kelompok perikanan pada bu- 
lan Februari 2016, di Kabupaten Pangandaran sebanyak 491 kelompok dengan jumlah pelaku utama sebanyak 6.791 orang yang tersebar di 10 Kecamatan. Kelas kelompok didominasi oleh kelas pemula yang berjumlah 393 kelompok, sedangkan kelas madya berjumlah 98 kelompok. Berdasarkan bidang usaha, terdapat 328 kelompok usaha budidaya, 131 kelompok penangkapan ikan, serta 32 kelompok pengolahan dan pemasaran.

Salah satu usaha perikanan yang sedang berkembang saat ini di Kabupaten Pangandaran adalah usaha pengolahan, pemasaran ikan dan penangkapan ikan yang dilaksanakan masyarakat Pangandaran. Adapun faktor pendukung dalam perkembangan usaha perikanan meliputi kondisi wilayah perairan dan produksi perikanan baik budidaya maupun penangkapan yang mendukung ketersediaan jumlah bahan baku. Tidak hanya potensi usaha, Kabupaten Pangandaran juga memiliki potensi sebagai salah satu daerah wisata bahari yang banyak dikunjungi wisatawan lokal maupun internasional sehingga dapat meningkatkan perekonomian masyarakat setempat.

Teknologi produksi kelautan dan perikanan terus berkembang dan meningkat. Untuk itu, upaya penye- baran inovasi teknologi kepada pelaku usaha perikanan juga perlu ditingkatkan. Mengomunikasikan inovasi teknologi sampai dapat diterima dan diterapkan oleh masyarakat bukan suatu hal yang mudah dan sederhana, karena masih banyak dijumpai kasus kegagalan atau tidak efektifnya penerapan teknologi oleh masyarakat di Indonesia. Tidak efektifnya dan atau kegagalan penerapan teknologi oleh masyarakat disebabkan antara lain: 1) Ada pendekatan yang salah dari sistem sumber daya dalam komunikasi, 2) Teknologi yang dikembangkan sering kali tidak sesuai dengan kebutuhan masyarakat, 3) Kehilangan konsep dalam pengemasan informasi (pesan) dan memilih media, 4) Pendekatan komunikasi teknologi kelautan dan perikanan belum mempertimbangkan aspek lokasi untuk meningkatkan efektivitas prosesnya (Padmaningrum 2008). Berdasarkan uraian di atas, penelitian ini bertujuan untuk 1) mengetahui strategi komunikasi dalam penerapan teknologi para pelaku usaha perikanan di Kabupaten Pangandaran dengan mengidentifikasi terlebih dahulu karakteristik internal yang terdiri dari umur, pendapatan, jumlah keluarga, lama usaha, pendapatan, pengeluaran dan motif usaha maupun karakteristik eksternal yang terdiri dari 
pelatihan, pendampingan dan bantuan dari pemerintah setempat sehingga dapat mengetahui efektivitas dari penerapan teknologi tersebut.

\section{METODOLOGI}

\section{Lokasi dan Waktu Penelitian}

Penelitian ini dilaksanakan pada bulan Mei-Agustus 2018 pada wilayah pesisir selatan Kabupaten Pangandaran Jawa Barat. Lokasi penelitian ini terdiri dari 2 (dua) kecamatan yaitu Kecamatan Parigi dan Kecamatan Cijulang. Kecamatan Parigi di Desa Karangjaladri dan Kecamatan Cijulang di Desa Batukaras.

\section{Jenis dan Metode Pengambilan Data}

Penelitian ini menggunakan pendekatan kuantitatif untuk mengetahui adanya pengaruh antar variabel yang dilakukan dengan uji statistik dan untuk menjelaskan hasil uji tersebut menggunakan data kualitatif. Metode penelitian kualitatif adalah prosedur penelitian yang menghasilkan data deskriptif berupa kata-kata tertulis atau lisan dari orang/ responden serta pengamatan perilaku responden (Muljono 2012). Metode penelitian kualitatif dalam penelitian ini berdasarkan paradigma penelitian partisipatoris yang artinya bahwa suatu proyek penelitian dilakukan secara kolaboratif dengan masyara- kat, analisis berbasis masalah-masalah sosial masyarakat, dan berorientasi pada tindakan masyarakat (Kemmis dan McTaggart 2005)

Menurut Sugiyono (2012) pengambilan data dari responden dalam metode kualitatif berkembang terus secara bertujuan (purposive) hingga data yang dikumpulkan dianggap jenuh artinya jawaban berulang. Alat pengumpul data penelitian dalam metode kualitatif adalah peneliti itu sendiri. Peneliti harus secara aktif turun ke lapangan dan mengambil langsung dari responden.

Teknik pengumpulan data yang digunakan adalah survei serta diskusi kelompok terbatas (Focus Group Discussion), wawancara/tanya jawab, dan dokumentasi. Focus Group Discussion dilaksanakan dengan melibatkan 8 (delapan) orang penyuluh perikanan dan responden wawancara melibatkan pelaku usaha perikanan di Kabupaten Pangandaran. Data yang didapat dari penelitian ini ialah data yang disajikan dalam bentuk verbal, bukan dalam angka. Data kata verbal yang beragam tersebut perlu diolah agar menjadi ringkas sistematis. Proses olahan data tersebut mulai dari mencatat hasil observasi, wawasan/merekam, mengedit, mengelompokkan, dan mereduksi. Data penelitian melalui pendekatan kuan- 
titatif yang didukung dengan pendekatan kualitatif diperoleh melalui survei langsung di lapangan yaitu terhadap:

a) Data karakteristik internal masyarakat pesisir pelaku usaha pengolahan dan penangkapan ikan,

b) Data program kegiatan pemerintah Kabupaten Pangandaran terkait usaha pengolahan ikan dan penangkapan ikan.

Pengumpulan data sekunder dilakukan dengan mengambil data dari instansi/lembaga pemerintah yang berwewenang dalam program pembangunan kelautan dan perikanan di Kabupaten Pangandaran yaitu Dinas Kelautan. Data yang diambil berupa data-data yang berhubungan secara langsung maupun tidak langsung terkait ke dalam dengan permasalahan yang diteliti dan juga data dari berbagai pustaka melalui buku, jurnal, dan atau artikel.

\section{Metode Analisis}

Metode analisis data yang digunakan dalam kegiatan penelitian ini adalah sebagai berikut:

a) Reduksi data

Data yang diperoleh dari lapangan dituangkan ke dalam bentuk laporan melalui alat pengumpulan data berupa kuesioner dan depth interview untuk mendukung jawab- an yang telah tertuang dalam kuesioner kemudian tahap selanjutnya di reduksi, dirangkum, difokuskan pada hal-hal penting sesuai dengan tema mengenai strategi komunikasi. Data yang direduksi memberikan fokus gambaran yang lebih dalam tentang hasil pengamatan serta juga mempermudah dalam mencari data kembali yang diperoleh bila diperlukan.

b) Penyajian Data

Untuk melihat gambaran keseluruhan dan atau bagian-bagian tertentu dari penelitian, dapat disajikan dalam bentuk matriks, grafik, jaringan, dan bagian serta dalam bentuk naratif dan atau gabungan dari beberapa bentuk sajian tersebut.

Data yang diperoleh, diolah dan analisis secara kuantitatif dan kualitatif. Analisis statistik deskriptif dilakukan untuk mendeskripsikan variabel-variabel dalam penelitian ini. Analisis statistik deskriptif dilakukan melalui: a) penyajian data peubah dengan metode tabulasi; b) penentuan kecenderungan nilai responden untuk masing-masing peubah yang dikelompokkan menjadi tiga kelas kategori masingmasing adalah: 1) rendah, 2) sedang, dan 3) tinggi. Namun, kategori tersebut tidak berlaku untuk 
skala data nominal. Rumus yang digunakan untuk menentukan interval kelas adalah sebagai berikut:

Interval Kelas $=\frac{\text { Nilai } T-\text { Nilai } R}{3}$

Keterangan:

Nilai T : Nilai Tertinggi

Nilai R : Nilai Terendah

c) Verifikasi Data (Pengambilan Kesimpulan.)

Verifikasi data atau pengambilan kesimpulan didasarkan pada hubungan yang ada pada data yang tersaji. Peneliti menyusun arti, pola, tema, yang penjelasan alur sebab akibat, dan sebagainya dari data yang ada. Kesimpulan harus dapat diuji selama penelitian berlangsung, sehingga memungkinkan dilakukan pencarian/penambahan data baru.

Proses analisis dilakukan terhadap data yang didapat. Analisis data menggunakan metode deskriptif kualitatif yang diperkuat oleh data dan informasi pendukung. Adapun informasi pendukung dalam penelitian ini berkaitan dengan kegiatan pelatihan, bantuan yang diterima pelaku usaha perikanan dan pendampingan penyuluh. Rangkuman deskriptif untuk menjelaskan pola variabel penyebab dan tujuan dalam menjelaskan fakta di lapangan (Rakhmat 2014). Selain itu, proses analisis data dilakukan dengan analisis interaktif yaitu analisis data yang dilakukan bersamaan dengan proses pelaksanaan pengumpulan data. Data yang diperlukan dalam kegiatan penelitian ini adalah data primer yang diperoleh dengan melakukan observasi lapangan baik itu pengamatan fisik maupun wawancara terhadap responden wawancara yang terpilih yaitu pengolah dan pemasar produk perikanan.

\section{HASIL DAN PEMBAHASAN}

Hasil

Penerapan informasi teknologi, strategi komunikasi, dan teknologi berada pada kategori sedang. Penerapan informasi teknologi pelaku usaha perikanan di pesisir selatan Pangandaran berada pada kategori sedang sebesar $47 \%$. Hal ini merupakan bukti bahwa pelatihan, pendampingan, dan bantuan yang pernah diberikan oleh penyuluh kepada kelompok pelaku usaha perikanan berhasil dengan baik. Pelatihan yang dilaksanakan di Kabupaten Pangandaran kepada pelaku usaha perikanan dapat melibatkan Pusat Pelatihan Mandiri Kelautan dan Perikanan (P2MKP) yang bersinergi dengan kegiatan penyuluhan perikanan (Razi, Mardiyah, dan Kasmawijaya 2018). 
Tabel 1. Hubungan Penerapan Informasi teknologi, Strategi

Komunikasi dan Motivasi

\begin{tabular}{|c|c|c|c|c|}
\hline $\begin{array}{l}\mathbf{N} \\
\mathbf{0}\end{array}$ & Peubah & $\begin{array}{c}\text { Katego } \\
\text { ri } \\
\text { (skor) }\end{array}$ & $\begin{array}{c}\text { Juml } \\
\text { ah } \\
\text { (oran } \\
\text { g) }\end{array}$ & $\begin{array}{c}\text { Pers } \\
\text { enta } \\
\text { se } \\
(\%) \\
\end{array}$ \\
\hline \multirow[t]{3}{*}{1} & $\begin{array}{l}\text { Penerapa } \\
\mathrm{n}\end{array}$ & $\begin{array}{l}\text { Rendah } \\
(37-42)\end{array}$ & 11 & 37 \\
\hline & $\begin{array}{l}\text { Informasi } \\
\text { Teknologi }\end{array}$ & $\begin{array}{l}\text { Sedang } \\
(43-47)\end{array}$ & 14 & 47 \\
\hline & & $\begin{array}{l}\text { Tinggi } \\
(48-52)\end{array}$ & 5 & 16 \\
\hline \multirow[t]{3}{*}{2} & $\begin{array}{l}\text { Strategi } \\
\text { Komunik }\end{array}$ & $\begin{array}{l}\text { Rendah } \\
(46-54)\end{array}$ & 6 & 20 \\
\hline & asi & $\begin{array}{l}\text { Sedang } \\
(55-62)\end{array}$ & 15 & 50 \\
\hline & & $\begin{array}{l}\text { Tinggi } \\
(63-70)\end{array}$ & 9 & 30 \\
\hline \multirow[t]{3}{*}{3} & Motivasi & $\begin{array}{l}\text { Rendah } \\
(20-23)\end{array}$ & 9 & 30 \\
\hline & & $\begin{array}{l}\text { Sedang } \\
(24-26)\end{array}$ & 12 & 40 \\
\hline & & $\begin{array}{l}\text { Tinggi } \\
(27-29)\end{array}$ & 9 & 30 \\
\hline
\end{tabular}

Strategi komunikasi yang dilakukan oleh penyuluh kepada pelaku usaha perikanan berada pada kategori sedang sebesar $50 \%$ artinya bahwa proses komunikasi dengan membawa pesan penyuluhan oleh penyuluh sebagai komunikator dapat diterima dengan baik oleh pelaku usaha sebagai komunikan sehingga pada akhirnya sasaran dapat menerapkan teknologi baru yang didifusikan oleh penyuluh. Berdasarkan wawancara mendalam (depth inter- view) kepada delapan penyuluh perikanan pesisir selatan Pangandaran serta hasil kuesioner dari 30 responden bahwa strategi komunikasi yang paling efektif melalui komunikasi kelompok secara langsung (face to face) antara penyuluh dengan kelompok usaha perikanan melalui teknik penyuluhan kunjungan rumah dengan berkunjung langsung ke salah satu rumah mereka (door to door) terutama rumah ketua kelompok, karena kepemimpinan ketua kelompok dalam mengatur anggota kelompok terbukti efektif untuk mencapai tujuan kelompok demi kepentingan bersama (Nurmalia dan Susilawati 2016). Kepemimpinan ketua kelompok juga terbukti berhubungan erat terhadap partisipasi anggota kelompok (Leilani dan Restuwati 2016). Pelaku usaha perikanan sering sulit berkumpul untuk berdiskusi pada suatu tempat terutama bagi kegiatan penyuluhan dengan penyuluh yang belum pernah mereka kenal sebelumnya.

Motivasi pelaku usaha perikanan untuk mendapatkan informasi dalam kegiatan penyuluhan berada pada kategori sedang sebesar $40 \%$ dengan kecenderungan mendengarkan lebih besar dibandingkan dengan berpendapat dalam setiap diskusi kelompok. Motivasi yang artinya bahwa 
dorongan kuat para pelaku usaha perikanan untuk melibatkan diri dalam kegiatan penyuluhan untuk mendapatkan informasi sehingga dapat menerapkan teknologi/inovasi baru dengan tujuan supaya usaha mereka dapat berkembang melalui perubahan pengetahuan, sikap dan keterampilan.

Karakteristik responden terdiri dari umur, pendidikan, jumlah keluarga, jenis usaha, lama usaha, pendapatan, pengeluaran dan motif usaha. Responden pelaku usaha perikanan berjumlah 30 orang yang terdiri dari 3 orang pelaku usaha budidaya, 16 orang pelaku usaha tangkap, dan 11 orang pelaku usaha pengolahan. Sebagian besar responden berumur 36-45 tahun, dan tergolong umur produktif dengan latar belakang pendidikan yang didominasi SD/MI sebesar $40 \%$, responden dengan pendidikan diploma dan sarjana masing-masing hanya $3 \%$. Hal ini memperlihatkan bahwa sebagian besar responden memiliki latar belakang pendidikan rendah walaupun pengalaman usaha mereka rata-rata lebih dari 10 tahun.

Motif usaha mereka didominasi karena motivasi intrinsik atas dasar kemauan diri mereka sendiri karena usaha perikanan yang menguntungkan sebesar $43 \%$, bukan karena motivasi ekstrinsik yang merupakan dorongan dari pihak luar, usaha turun menurun ataupun tidak ada pekerjaan lain yang bisa ditekuni. Pendapatan dan pengeluaran responden pada rentang nominal Rp1.000.001Rp1.500.000 sebesar $33 \%$ dan $43 \%$.

Tabel 2. Karakteristik Internal Pelaku Usaha

\begin{tabular}{|c|c|c|c|c|}
\hline $\begin{array}{l}\mathbf{N} \\
\mathbf{0}\end{array}$ & $\begin{array}{l}\text { Peub } \\
\text { ah }\end{array}$ & Kategori & $\begin{array}{c}\mathrm{Ju} \\
\mathrm{ml} \\
\text { ah } \\
\text { (o } \\
\mathrm{ra} \\
\mathrm{ng} \\
\text { ) }\end{array}$ & $\begin{array}{c}\text { Pre } \\
\text { sen } \\
\text { tase } \\
(\%)\end{array}$ \\
\hline \multirow[t]{6}{*}{1} & \multirow[t]{6}{*}{ Umur } & $15-25$ tahun & 0 & 0 \\
\hline & & $26-35$ tahun & 3 & 10 \\
\hline & & $36-45$ tahun & 14 & 47 \\
\hline & & $46-55$ tahun & 7 & 23 \\
\hline & & $56-65$ tahun & 6 & 20 \\
\hline & & $>65$ tahun & 0 & 0 \\
\hline \multirow[t]{6}{*}{2} & Pendi & Tidak Sekolah & 1 & 3 \\
\hline & dikan & SD/MI & 12 & 40 \\
\hline & Form & SLTP/MTS & 7 & 23 \\
\hline & & SLTA/MA & 8 & 27 \\
\hline & & DIII/Diploma & 1 & 3 \\
\hline & & Sarjana & 1 & 3 \\
\hline \multirow[t]{4}{*}{3} & Jumla & 1-2 orang & 11 & 37 \\
\hline & & 3-5 orang & 17 & 57 \\
\hline & Kelua & 6-9 orang & 2 & 7 \\
\hline & & $>9$ orang & 0 & 0 \\
\hline \multirow[t]{3}{*}{4} & Jenis & Budidaya & 3 & 10 \\
\hline & Usah & Tangkap & 16 & 53 \\
\hline & a & Pengolahan & 11 & 37 \\
\hline \multirow[t]{4}{*}{5} & Lama & $<1$ tahun & 1 & 3 \\
\hline & Usah & $1-5$ tahun & 8 & 27 \\
\hline & a & 6-10 tahun & 2 & 7 \\
\hline & & $>10$ tahun & 19 & 63 \\
\hline \multirow[t]{6}{*}{6} & Pend & $<\operatorname{Rp} 500,000$ & 8 & 27 \\
\hline & $\begin{array}{l}\text { apata } \\
\mathrm{n}\end{array}$ & $\begin{array}{l}\text { Rp500,001 - } \\
\text { Rp } 1,000,000\end{array}$ & 4 & 13 \\
\hline & & $\begin{array}{l}\text { Rp1,000,001 - } \\
\text { Rp } 1,500,000\end{array}$ & 10 & 33 \\
\hline & & $\begin{array}{l}\text { Rp1,500,001 - } \\
\operatorname{Rp} 2,000,000\end{array}$ & 3 & 10 \\
\hline & & $\begin{array}{l}\text { Rp2,000,001 - } \\
\text { Rp2,500,000 }\end{array}$ & 2 & 7 \\
\hline & & $>\mathrm{Rp} 2,500,000$ & 3 & 10 \\
\hline
\end{tabular}




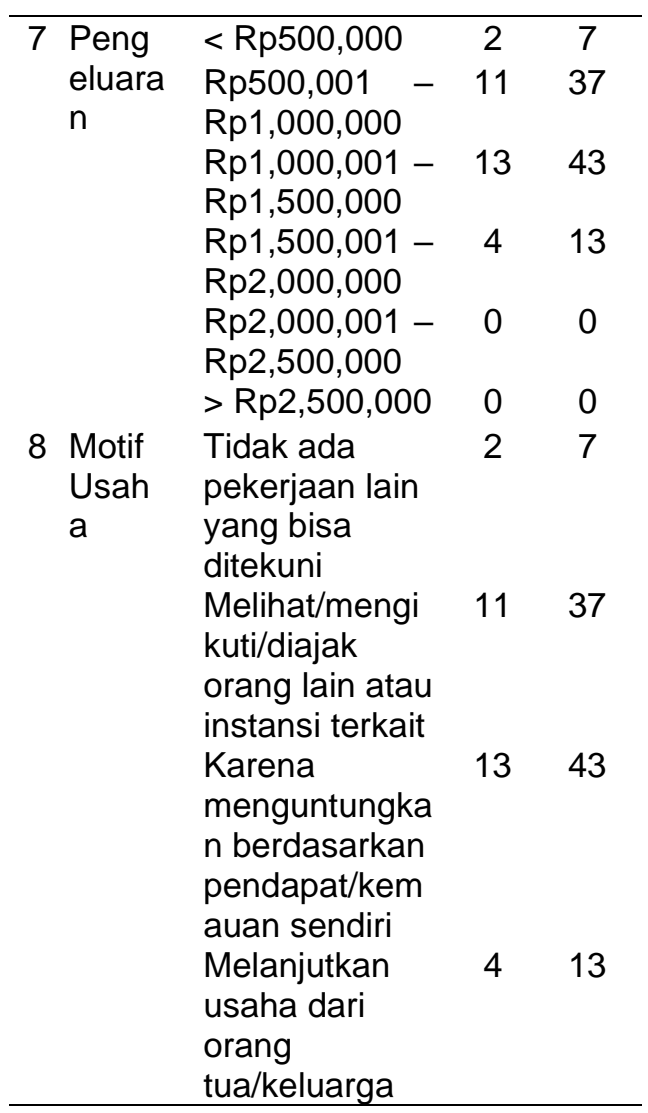

Karakteristik eksternal penyuluh didominasi pernah mengikuti atau terlibat pelatihan dalam 1 tahun terakhir dan pendampingan/penyuluhan sebesar $60 \%$ dan $93 \%$. Sedangkan, $73 \%$ responden pernah mendapatkan bantuan dari pemerintah setempat. Menurut responden, pelatihan, pendampingan dan bantuan memiliki manfaat untuk perkembangan usaha sehingga dapat meningkatkan pendapatan yang diperoleh.

Tabel 3. Karakteristik Eksternal Pelaku Usaha

\begin{tabular}{ccccc}
\hline $\mathbf{N}$ & $\begin{array}{c}\text { Peuba } \\
\mathbf{0}\end{array}$ & $\begin{array}{c}\text { Kate } \\
\text { gori }\end{array}$ & $\begin{array}{c}\text { Jumla } \\
\text { h }\end{array}$ & $\begin{array}{c}\text { Perse } \\
\text { ntase } \\
(\%)\end{array}$ \\
\hline
\end{tabular}

\begin{tabular}{|c|c|c|c|c|}
\hline & & \multicolumn{3}{|c|}{$\begin{array}{c}\text { (orang } \\
\text { ) }\end{array}$} \\
\hline \multirow[t]{2}{*}{1} & $\begin{array}{l}\text { Pelatih } \\
\text { an } \\
\text { dalam }\end{array}$ & $\begin{array}{l}\text { Tidak } \\
\text { Perna } \\
\text { h }\end{array}$ & 12 & 40 \\
\hline & $\begin{array}{l}1 \\
\text { tahun } \\
\text { terakhi } \\
r\end{array}$ & $\begin{array}{l}1-2 \\
\text { kali }\end{array}$ & 18 & 60 \\
\hline \multirow[t]{2}{*}{2} & $\begin{array}{l}\text { Penda } \\
\text { mping }\end{array}$ & $\begin{array}{l}\text { Tidak } \\
\text { Ada }\end{array}$ & 2 & 7 \\
\hline & an & Ada & 28 & 93 \\
\hline \multirow[t]{2}{*}{3} & $\begin{array}{l}\text { Bantu } \\
\text { an }\end{array}$ & $\begin{array}{l}\text { Tidak } \\
\text { Perna } \\
h\end{array}$ & 8 & 27 \\
\hline & & $\begin{array}{l}\text { Perna } \\
\text { h }\end{array}$ & 22 & 73 \\
\hline
\end{tabular}

Hasil penelitian menunjukkan karakteristik internal dan eksternal pelaku usaha perikanan di pesisir selatan Pangandaran memiliki pengaruh secara simultan dengan penerapan teknologi karena f hitung sebesar 2,50 > f tabel sebesar 2,537 dan nilai signifikasi sebesar $0,098<$ 0,1 dengan tingkat kepercayaan sebesar $90 \%$ yang berarti semakin tinggi karakteristik internal (umur, pendidikan formal, jumlah keluarga, lama usaha, jenis usaha, pendapatan, pengeluaran dan motif usaha) dan eksternal (pelatihan dalam 1 tahun terakhir, pendampingan/penyuluhan dan bantuan) pelaku usaha perikanan berpengaruh terhadap peningkatan penerapan informasi teknologi dan sebaliknya. Hal ini juga sejalan dengan hasil penelitian Darwita, Danapraja, dan Leilani (2018) bahwa karakteristik internal pembudidaya diantaranya umur, pendidikan, penda- 
patan, dan lama usaha di Kecamatan Darmaraja Kabupaten Sumedang berpengaruh terhadap kecepatan penerapan teknologi.

Penerapan teknologi berpengaruh terhadap strategi komunikasi yang diterapkan pelaku usaha perikanan karena $t_{\text {hitung }}$ sebesar 2,307> $t_{\text {tabel }}$ sebesar 2,048 dan nilai signifikasi sebesar $0,000<0,05$ dengan tingkat kepercayaan sebesar $95 \%$ yang berarti semakin tinggi penerapan informasi teknologi yang diterapkan berpengaruh terhadap peningkatan strategi komunikasi yang digunakan. Pelaku usaha perikanan dapat semakin mampu menerapkan informasi yang diperoleh terhadap teknologi/ inovasi baru dengan didukung oleh strategi komunikasi penyuluh dalam menyampaikan pesan.

Strategi komunikasi berpengaruh terhadap motivasi pelaku usaha perikanan karena thitung sebesar 5,574 $>t_{\text {tabel }}$ sebesar 2,048 dan nilai signifikasi sebesar 0,03<0,05 dengan tingkat kepercayaan sebesar $95 \%$ yang berarti strategi komunikasi yang semakin tinggi akan berpengaruh terhadap peningkatan motivasi pelaku usaha perikanan. Hal ini berarti strategi komunikasi yang digunakan baik dari komunikator (keterampilan atau metode dalam menyampaikan pesan), pesan (isi dan daya tarik pesan).
Media yang digunakan (baik itu media visual, audio atau media audio visual) serta komunikan (kemampuan, kesadaran, dan perhatian dalam menerima pesan) harus tepat atau sesuai dengan tujuan untuk mengubah perilaku pelaku usaha perikanan yang didukung oleh motivasi mereka sendiri dalam melibatkan diri pada kegiatan penyuluhan, pelatihan/ kursus dan seminar/diskusi.

\section{Pembahasan}

Perkembangan usaha perikanan masyarakat dapat didukung melalui kegiatan pendampingan atau penyuluhan yang dilaksanakan oleh pemerintah daerah baik berupa informasi teknologi, pemberian motivasi dalam berwirausaha (entrepreneur motivation), dan peningkatan keterampilan pelaku usaha merupakan salah satu solusi dalam membantu mengembangkan usaha perikanan masyarakat di pesisir selatan $\mathrm{Pa}$ ngandaran. Menurut Razi (2014) penyuluhan merupakan salah satu kegiatan dalam rangka pemberdayaan masyarakat perikanan dalam pengelolaan usaha perikanan, sehingga pengembangan usaha perikanan masyarakat di Kabupaten Pangandaran merupakan salah satu bentuk pemberdayaan masyarakat pesisir. Tujuan utama kegiatan 
penyuluhan atau pendampingan tersebut supaya dapat mengubah perilaku sasaran dalam hal ini pelaku usaha perikanan sehingga mereka dapat meningkatkan pendapatan yang berpengaruh besar dalam peningkatan taraf hidup dengan berlandaskan pada salah satu falsafah penyuluhan yaitu kemandirian yang artinya dapat mengubah nasibnya sendiri (Nurfitriana dan Razi 2018). Tujuan penyuluhan perikanan dapat terealisasikan atau keberhasilan proses penyuluhan karena terjalinnya komunikasi yang efektif antara penyuluh dan sasaran (Razi 2010)

Penerapan informasi teknologi (Tabel 1) menunjukkan bahwa keberhasilan proses komunikasi yang terjadi telah dapat diwujudkan antara penyuluh sebagai komunikator dan pelaku usaha perikanan sebagai komunikan, sehingga komunikan mampu menerapkan teknologi yang merupakan hasil dari kegiatan penyuluhan yang selama ini mereka ikuti. Hal ini sejalan dengan hasil penelitian Ratnadila, Taryoto, dan Leilani (2019) bahwa setelah adanya kegiatan penyuluhan di Kabupaten Tabanan Bali, sasaran penyuluhan banyak merasakan manfaat dari adanya teknologi informasi dan tidak sedikit dari mereka yang menerapkannya dalam kegiatan yang mereka lakukan. Pada dasarnya pelaku usaha perikanan di pesisir selatan Pangandaran mendukung kegiatan penyuluhan yang merupakan program pemerintah. Sebagian besar responden (56 \%) sangat antusias dalam mengikuti kegiatan tersebut dengan tujuan supaya usaha mereka dapat berkembang. Teknologi atau inovasi baru yang diperkenalkan oleh penyuluh dapat memberikan keuntungan yang lebih dibandingkan dengan teknologi atau inovasi lama.

Hasil penelitian Razi (2015) yang menyatakan bahwa kegiatan penyuluhan budidaya perikanan berbasis keterampilan adalah strategi yang paling efektif di daerah perkotaan seperti Kota Bogor, sehingga hal tersebut sejalan dengan hasil penelitian ini yang menyatakan bahwa kegiatan penyuluhan perikanan yang paling tepat dengan menggunakan strategi komunikasi kelompok secara langsung/directly salah satunya dengan peningkatan keterampilan. Tabel 1 menunjukkan bahwa strategi komunikasi kelompok merupakan strategi komunikasi yang tepat untuk dilaksanakan dengan melibatkan ketua kelompok. Kepemimpinan ketua kelompok juga terbukti berhubungan erat terhadap partisipasi anggota kelompok (Leilani dan Restuwati 2016). Pelaku usaha perikanan sering sulit berkumpul untuk berdiskusi pada 
suatu tempat terutama bagi kegiatan penyuluhan dengan penyuluh yang belum pernah mereka kenal sebelumnya. Menurut Notoatmodjo (2012) metode penyuluhan yang tepat dilaksanakan merupakan metode penyuluhan melalui pendekatan kelompok kecil antara lain diskusi kelompok, curah pendapat (brain storming), memainkan peran (role play) dan permainan simulasi (simulation game). Komunikasi kelompok yang terjalin juga didukung oleh media visual dan audio visual untuk lebih memperjelas inovasi baru yang akan disampaikan sepeti video, folder serta brosur/ leaflet. Hal ini sejalan dengan yang diutarakan oleh Devito (2011) bahwa strategi komunikasi harus dapat memperhitungkan efek komunikasi yang diharapkan terjadi, sehingga dapat ditetapkan bentuk/teknik atau cara berkomunikasi yang akan diterapkan, seperti memanfaatkan komunikasi langsung/tatap muka (face to face communication) untuk memunculkan efek perubahan perilaku (behaviour change) pada penerima pesan. Pemanfaatan komunikasi berbasis media (media based communication), yang bersifat informatif dengan jangkauan jumlah komunikan yang lebih banyak, tetapi lebih lemah dalam fungsi persuasif.
Berdasarkan jawaban responden melalui kuesioner bahwa sebesar $80 \%$ lebih tertarik terhadap media audio visual dalam kegiatan penyuluhan dibandingkan hanya media visual. Apabila penyuluh telah menyalurkan semua informasi teknologi kepada kelompok usaha perikanan, kemudian dilanjutkan dengan mempraktikkan inovasi baru tersebut dengan didukung oleh media praktik yang dibutuhkan dan disesuaikan dengan tema penyuluhan. Kegiatan penyuluhan dilakukan melalui pendekatan komunikasi yang tepat dengan mempertimbangkan struktur sosial pelaku usaha perikanan yang bergabung dalam kelompok usaha perikanan tertentu diantaranya umur, jenis usaha, bahasa, budaya/kebiasaan, pendidikan, dan agama. Strategi komunikasi yang digunakan melalui komunikasi kelompok dapat mengubah perilaku pelaku usaha perikanan baik pengetahuan, sikap dan keterampilan kelompok dalam menjalankan usaha. Perubahan perilaku tersebut dapat meningkatkan produksi mereka sehingga dapat meningkatkan pendapatan yang pada akhirnya meningkatkan kesejahteraan mereka, hal tersebut juga sejalan dengan pernyataan Mardikanto (2009).

Motivasi (Tabel 1) yang bertujuan untuk perubahan perilaku me- 
rupakan wujud intensitas keterlibatan mereka dalam pelatihan, kursus, seminar, diskusi maupun penyuluhan. Hal ini sejalan dengan apa yang dikemukakan oleh (Anas 2003) semakin besar minat, relevansi program dan harapan pelaku utama perikanan semakin efektif komunikasi yang terjadi dalam meningkatkan pengetahuan, keterampilan dan menentukan sikap.

Kegiatan pendampingan atau penyuluhan (Tabel 3) yang dilakukan penyuluh terhadap pelaku usaha perikanan di pesisir selatan Pangandaran terdiri dari pendampingan dalam pembinaan kelompok dan pendampingan usaha. Pendampingan dalam pembinaan kelompok berupa manajemen (pemanfaatan kebijakan dan bantuan pemerintah), administrasi (pendampingan pendirian akta badan kelompok) dan pengelolaan keuangan, sedangkan pendampingan usaha berupa teknik produksi, teknologi, modal dan akses pasar seperti usaha penggaraman sistem tunnel dan usaha budidaya ikan sistem bioflok. Kendala penyuluh melakukan kegiatan pendampingan pelaku usaha perikanan yaitu kelompok kurang respons terhadap program pemerintah, materi penyuluhan yang kurang diterapkan, media penyuluhan yang terbatas, dan jarak antar pelaku usaha perikanan berjauhan sehingga sulit menentukan waktu pertemuan. Adapun pelatihan dan pendampingan/ penyuluhan yang pernah mereka ikuti diantaranya mengenai manajemen kelompok khususnya administrasi kelompok termasuk laporan keuangan, mesin, alat tangkap, pengolahan, dan budidaya ikan, selain itu bantuan yang pernah mereka dapatkan berupa bantuan modal dana, alat tangkap, perahu/mesin dan alat pengolahan.

\section{SIMPULAN DAN SARAN}

\section{Simpulan}

Berdasarkan penelitian yang dilaksanakan, dapat disimpulkan beberapa hal sebagai berikut yaitu semakin tinggi karakteristik internal dan eksternal pelaku usaha perikanan di Kabupaten Pangandaran semakin tinggi peningkatan penerapan teknologi begitu pula sebaliknya. Strategi komunikasi yang paling efektif adalah komunikasi yang informatif dan persuasif secara langsung (face to face) antara penyuluh dengan kelompok usaha perikanan dengan berkunjung langsung ke salah satu rumah mereka (door to door). Sebagian besar pelaku usaha perikanan di Kabupaten Pangandaran sangat antusias dalam mengikuti perkembangan teknologi atau inovasi baru yang diperkenalkan dan dapat memberikan 
keuntungan yang lebih besar. Sehingga teknologi baru yang diperkenalkan kepada pelaku usaha perikanan merupakan teknologi yang sesuai kebutuhan dan pada akhirnya berdampak pada perolehan pendapatan yang lebih besar.

\section{Saran}

Guna meningkatkan keberhasilan kegiatan pemberdayaan dan peningkatan usaha perikanan masyarakat Kabupaten Pangandaran, maka disarankan beberapa hal berikut: 1) Perlu transfer Informasi pengetahuan dan teknologi menggunakan metode demonstrasi cara agar dapat lebih meningkatkan keterampilan pelaku usaha; 2). perlunya adanya kegiatan pendampingan, pembinaan yang kontinu terutama oleh penyuluh terkait segmen kegiatan usaha baik pengolahan. pemasaran dan penangkapan ikan kepada nelayan, pengolah dan pemasar ikan.

\section{PERSANTUNAN}

Penulis mengucapkan terima kasih kepada Kepala Badan Riset dan Sumber Daya Manusia Kelautan dan Perikanan, Sekretaris Badan Riset dan Sumber Daya Manusia Kelautan dan Perikanan, Kepala Pusat Pendidikan, Direktur Politeknik Ahli Usaha Perikanan, Kepala Unit Praktik
Lapang Komunikasi dan Penyuluhan Politeknik AUP sehingga jurnal ini dapat diterbitkan.

\section{DAFTAR PUSTAKA}

Anas, Pigoselpi. 2003. "Efektifitas

$$
\begin{aligned}
& \text { Komunikasi Program } \\
& \text { Pemberdayaan Ekonomi } \\
& \text { Masyarakat Pesisir (Kasus } \\
& \text { Cilincing dan Kepulauan Seribu) } \\
& \text { [Tesis]." Institut Pertanian Bogor. }
\end{aligned}
$$

Arifin, Anwar. 1984. Strategi komunikasi: sebuah pengantar ringkas. Bandung (ID): Penerbit Armico.

Badan Pengembangan Sumber Daya Manusia Kelautan dan Perikanan. 2016. "KKP Tingkatkan Kelas Kelompok Masyarakat Perikanan." BPSDMKP. Diambil 5 Juni 2020 (http://www.bpsdmkp.kkp.go.id/i ndex.php/detail/160223-081229kkp-tingkatkan-kelas-kelompokperikanan-untuk-kesejahteraanmasyarakat\#sthash.ICFP5kym.d pbs).

Baran, Stanley J., dan Dennis K. Davis. 2010. Teori Komunikasi Massa: Dasar, Pergolakan, dan Masa Depan. Jakarta (ID): Salemba Humanika.

BPS. 2019. Kabupaten Pangandaran dalam Angka Tahun 2019. Ciamis (ID): BPS Kabupaten 
Ciamis.

Darwita, Nisfi, Sopiyan Danapraja, dan Ani Leilani. 2018. "Hubungan Karakteristik Pembudidaya Ikan terhadap Adopsi Inovasi Pakan Alami Ikan di Kecamatan Darmaraja Kabupaten Sumedang." Jurnal Penyuluhan Perikanan dan Kelautan 12(3):195-201. doi: 10.33378/jppik.v12i3.109.

DeVito, Joseph A. 2011. Komunikasi Antarmanusia. Ed 5. diedit oleh A. Maulana. Tangerang (ID): Karisma Publishing Group.

Effendy, Onong Uchjana. 2013. IImu Komunikasi Teori dan Praktek. Bandung (ID): Remaja Rosdakarya.

Kemmis, Stephen, dan Robin McTaggart. 2005. "Participatory Action Research:

Communicative Action and the Public Sphere." Hal. 559-603 in The Sage handbook of qualitative research, diedit oleh N. K. Denzin dan Y. S. Lincoln. Sage Publication.

Leilani, Ani, dan Ina Restuwati. 2016.

"Partisipasi Nelayan dalam Kelompok Usaha Bersama Bidang Penangkapan Ikan (Kasus pada KUB di Kecamatan Pangandaran, Kabupaten
Pangandaran)." Jurnal Penyuluhan Perikanan dan Kelautan 10(1):60-70. doi: 10.33378/jppik.v10i1.68.

Mardikanto, Totok. 2009. Sistem Penyuluhan Pertanian. Surakarta (ID): UNS Press.

McQuail, Denis, dan Sven Windahl. 2015. Communication models: For the study of mass communications, second edition. Routledge.

Muljono, Pudji. 2012. Metode Penelitian Sosial. Bogor (ID): IPB Press.

Mulyana, Deddy. 2012. IImu Komunikasi Suatu Pengantar. Bandung (ID): Remaja Rosdakarya.

Notoatmodjo, Soekidjo. 2012. Promosi Kesehatan dan IImu Perilaku. Jakarta (ID): Rineka Cipta.

Nurfitriana, Nia, Anna Fatchiya, dan Djoko Susanto. 2016. "Perilaku Kewirausahaan Pelaku Usaha Pempek Skala Industri Kecil dan Menengah di Kota Palembang." Jurnal Penyuluhan 12(2):114. doi:

10.25015/penyuluhan.v12i2.114 70.

Nurfitriana, Nia, dan Fahrur Razi. 2018. Penyuluhan dan Kearifan 
Lokal Sahabat Kental Tak Lekang oleh Zaman. Bogor: STP Jurusan Penyuluhan Perikanan.

Nurmalia, Nayu, dan Tuti Susilawati. 2016. "Hubungan Kepemimpinan Ketua Kelompok dengan Keefektifan Kelompok." Jurnal Penyuluhan Perikanan dan Kelautan 10(2):71-87. doi: 10.33378/jppik.v10i2.69.

Padmaningrum, Dwiningtyas. 2008.

"Strategi Komunikasi dalam Mengantisipasi dan Memecahkan Kegagalan Penerapan Teknologi Oleh Petani." Agritexts Journal of Agricultural Extension 21(1). doi: 10.20961/agritexts.v23i1.43578.

Purnomo, Wahyono Hadi, Ani Leilani, dan Nia Nurfitriana. 2018. Penyuluhan Perikanan. Jakarta (ID): Amafrad Press.

Rakhmat, Jalaluddin. 2014. Metode Penelitian Komunikasi Dilengkapi Contoh dan Analisis Statistik. Bandung (ID): Remaja Rosdakarya.

Ratnadila, Nila Sylvi, Andin $\mathrm{H}$. Taryoto, dan Ani Leilani. 2019. "Pemanfaatan Media Teknologi Informasi dalam Penyelenggaraan Penyuluhan Perikanan (Kasus Penyuluh Perikanan Kabupaten Tabanan
Provinsi Bali)." Jurnal

Penyuluhan Perikanan dan

Kelautan 13(2):189-204. doi:

10.33378/jppik.v13i2.128.

Razi, Fahrur. 2010. Buku Pintar Kompetensi Dasar Bagi Penyuluh Perikanan. Jakarta (ID): Pusat Penyuluhan Kelautan Dan Perikanan.

Razi, Fahrur. 2014. "Kumpulan Makalah Learning Competence Pemberdayaan Masyarakat Perikanan."

Razi, Fahrur. 2015. "Analisis Prioritas Penyuluhan Perikanan di Wilayah Perkotaan pada Pengelolaan Usaha Budidaya Perikanan: Kasus di Kota Bogor [Tesis]." Universitas Terbuka.

Razi, Fahrur, Ainun Mardiyah, dan Adang Kasmawijaya. 2018. "Determinasi Peran dan Strategi Pengembangan Pusat Pelatihan Mandiri Kelautan dan Perikanan di Kalimantan Selatan." Jurnal Penyuluhan Perikanan dan Kelautan 12(1):21-31. doi: 10.33378/jppik.v12i1.98.

Sugiyono. 2012. Metode Penelitian Kuantitatif, Kualitatif dan $R \& D$. Bandung (ID): Alfabeta. 